\title{
Therapeutic aspects of cannabis and cannabinoids ${ }^{\dagger}$
}

PHILIP ROBSON

\section{Background Review commissioned in 1996 by the Department of Health $(\mathrm{DOH})$.}

\begin{abstract}
Aims Assess therapeutic profile of cannabis and cannabinoids.

Method Medline search, references supplied by $\mathrm{DOH}$ and others, and personal communications.
\end{abstract}

Results and Conclusions Cannabis and some cannabinoids are effective antiemetics and analgesics and reduce intraocular pressure. There is evidence of symptom relief and improved well-being in selected neurological conditions, AIDS and certain cancers. Cannabinoids may reduce anxiety and improve sleep. Anticonvulsant activity requires clarification. Other properties identified by basic research await evaluation. Standard treatments for many relevant disorders are unsatisfactory. Cannabis is safe in overdose but often produces unwanted effects, typically sedation, intoxication, clumsiness, dizziness, dry mouth, lowered blood pressure or increased heart rate. The discovery of specific receptors and natural ligands may lead to drug developments. Research is needed to optimise dose and route of administration, quantify therapeutic and adverse effects, and examine interactions.

\section{Declaration of interest Funding from $\mathrm{DOH}$. Between writing this paper and its acceptance for publication, P.R. was appointed Medical Director of GW Pharmaceuticals.}

†See editorial, p. 98, this issue.
In 1996 I was commissioned by the Department of Health (DOH) to review the scientific literature regarding the potential therapeutic utility of cannabis and its derivatives. The review was based upon primary sources (identified from a Medline literature search, reference lists supplied by the DOH and the Institute for the Study of Drug Dependence, and personal communications with relevant academics and clinicians). This paper is a greatly shortened version of the review. The 4 years which have elapsed have seen little in the way of new clinical results but considerable advances in cannabinoid basic science (Institute of Medicine, 1999). Government licences have recently been granted for several controlled trials of both synthetic and plant-derived cannabinoids in multiple sclerosis and chronic pain. In January 2000, I was appointed Medical Director of GW Pharmaceuticals, a company established to derive medicinal extracts from standardised cannabis plants.

\section{HISTORY OF THER APEUTIC USE}

The first formal report of cannabis as a medicine appeared in China nearly 5000 years ago when it was recommended for malaria, constipation, rheumatic pains and childbirth and, mixed with wine, as a surgical analgesic (Mechoulam, 1986). There are subsequent records of its use throughout Asia, the Middle East, Southern Africa and South America. Accounts by Pliny, Dioscorides and Galen remained influential in European medicine for 16 centuries.

It was not until the 19th century that cannabis became a mainstream medicine in Britain. W. B. O'Shaughnessy, an Irish scientist and physician, observed its use in India as an analgesic, anticonvulsant, antispasmodic, anti-emetic and hypnotic. After toxicity experiments on goats and dogs, he gave it to patients and was impressed with its muscle-relaxant, anticonvulsant and analgesic properties, and recorded its usefulness as an anti-emetic.

After these observations were published in 1842, medicinal use of cannabis expanded rapidly. It soon became available 'over the counter' in pharmacies and by 1854 it had found its way into the United States Dispensatory. The American market became flooded with dozens of cannabiscontaining home remedies.

Queen Victoria's personal physician wrote (Reynolds, 1890), on the basis of more than 30 years' experience, that "Indian hemp, when pure and administered carefully, is one of the most valuable medicines we possess". He found it incomparable for "senile insomnia", "night restlessness" and "temper disease" in both children and adults, but not helpful in melancholia, "very uncertain" in alcoholic delirium, and "worse than useless" in mania. It was very effective in neuralgia, period pains, migraine, "lightning pain of the ataxic patient" and gout, but useless in sciatica and "hysteric pains". $\mathrm{He}$ found it impressive in clonic spasms and certain epileptiform convulsions related to brain damage, but no good at all in petit mal or "chronic epilepsy", tetanus, chorea or paralysis agitans. It effectively relieved nocturnal cramps, asthma and dysmenorrhoea.

Reynolds was writing at a time when the zenith of cannabis as prescribed medicine and home remedy was already past. Although Sir William Osler was still recommending it for migraine sufferers in 1913, it was by then in steep decline because of variable potency of herbal preparations, poor storage stability, unpredictable response to oral administration, increasing enthusiasm for parenteral medicines and availability of potent synthetic alternatives, commercial pressures and American concern about recreational use. Cannabis was outlawed in 1928 by ratification of the 1925 Geneva Convention on the manufacture, sale and movement of dangerous drugs. Prescription remained possible until final prohibition under the 1971 Misuse of Drugs Act, against the advice of the Advisory Committee on Drug Dependence.

In the USA, medical use was effectively ruled out by the Marijuana Tax Act 1937 . This ruling has been under almost constant legal challenge and many special dispensations were made between 1976 and 1992 for individuals to receive 'compassionate 
reefers'. Although this loophole has been closed, a 1996 California state law permits cultivation or consumption of cannabis for medical purposes, if a doctor provides a written endorsement. Similar arrangements apply in Italy and Canberra, Australia.

\section{CANNABINOID PHARMACOLOGY RELEVANT TO THER APEUTICS}

Cannabinol was isolated in 1895 and cannabidiol in 1934, but the most significant discovery was that of $\Delta^{9}$-tetrahydrocannabinol (THC) in 1964. Chromatographic and spectroscopic methods subsequently uncovered many closely related compounds.

Capsules of synthetic THC (dronabinol) have been available for restricted medical use in the USA since 1985. Nabilone, a synthetic THC analogue, was marketed in 1983 and is the only cannabinoid licensed for prescription in the UK, restricted to treatment of nausea and vomiting caused by cytotoxic chemotherapy unresponsive to conventional anti-emetics. Use in other indications is only possible on a 'named patient' basis if the drug is supplied by a hospital pharmacy.

In 1988, a specific protein receptor (known as $\mathrm{CB}_{1}$ ) for THC was discovered in mouse nerve cells. This mediates most of the central nervous system (CNS) responses to cannabinoids, and is abundant in basal ganglia, hippocampus and cerebellum, globus pallidus, substantia nigra and cerebral cortex. An endogenous ligand was identified in 1992 and labelled anandamide (ananda: 'bliss' in Sanskrit). Anandamide has analgesic and tranquillising effects in animals, is involved in muscle coordination and affects the secretion and function of certain hormones. Other endogenous agonists almost certainly exist.

In 1993, a second receptor $\left(\mathrm{CB}_{2}\right)$ was identified in rat spleen macrophages, and this occurs only outside the CNS. There is scope for chemical manipulation of cannabinoids to maximise selectivity for $\mathrm{CB}_{2}$ and so avoid psychoactive effects. It is thought this receptor has relevance for anti-inflammatory and immunosuppressive activity.

Pertwee (1995) has suggested that the anandamide system might be concerned with mood, memory and cognition, perception, movement, coordination, posture and skeletal muscle tone, sleep, thermoregulation, appetite and immune response.

\section{CLINICAL APPLICATIONS}

\section{Nausea and vomiting}

Many cytotoxic drugs are powerful emetics, and this is the major limiting factor in patients' acceptance of cancer chemotherapy (see Table 1 and Appendix).

Many recreational smokers receiving cancer chemotherapy have told their doctors that cannabis relieved their nausea (Grinspoon \& Bakalar, 1993). Sallan et al's (1975) randomised control trial (RCT) compared oral THC and placebo in 22 cancer patients who had proved resistant to conventional anti-emetics. Comparisons using patients' self-reports of nausea and vomiting demonstrated that THC was statistically superior to placebo. THC $\left(10 \mathrm{mg} / \mathrm{m}^{2}\right)$ produced euphoria in the majority of patients, and one-third experienced sedation.

Subsequent RCTs (listed in Table 1) confirmed that natural and synthetic THC is invariably superior to placebo. Comparisons with anti-emetics available in the 1970s and 1980s suggest that THC is either equivalent in effect or better. A combination of prochlorperazine and THC was superior to either drug alone, and nabilone combined with prochlorperazine was better than dexamethazone plus metoclopramide. Although THC and nabilone produced more unwanted effects than comparison drugs, patients generally preferred them.

Children seem to respond well to nabilone and are tolerant of side-effects, but larger studies are required. $\Delta^{8}-\mathrm{THC}$ performed well in a pilot study (Abrahamov et al, 1995) involving eight children aged 3-13 years with various blood cancers receiving chemotherapy, $60 \%$ of whom had experienced distressing vomiting despite treatment with metoclopramide. $\Delta^{8}$-THC was given orally 2 hours before cytotoxics and repeated 6-hourly. No vomiting was recorded during this treatment and over the following 2 days. Two children were "slightly irritable" and one also showed "slight euphoria".

In a review of 12 studies involving 600 patients (Penta et al, 1981), THC was "effective" in $8 / 9$ and nabilone in $3 / 3$. The most common side-effects were somnolence $(33 \%)$, dry mouth $(9 \%)$, ataxia $(8 \%)$, dizziness $(6 \%)$, dysphoria $(6 \%)$, and orthostatic hypotension $(4 \%)$. A further review (Levitt, 1986) incorporating 55 studies, of which 32 were RCTs, showed that low-dose preventive treatment gives better results than targeting established vomiting. Younger patients may respond better than older ones.

Meta-analysis (Plasse et al, 1991) suggested that an optimal balance of efficacy and unwanted effects was achieved with relatively modest doses $\left(7 \mathrm{mg} / \mathrm{m}^{2}\right.$ or less). Sedation and psychotropic symptoms are commonly reported, but are usually mild to moderate in intensity and resolve rapidly on discontinuation. No "persistent or fatal" adverse effects have been reported. Many American oncologists encourage nauseous patients to try cannabis and would prescribe it if it were legal (Doblin \& Kleiman, 1991). Mode of action remains uncertain.

\section{Multiple sclerosis and other neurological conditions}

Drug therapy of muscle spasticity is generally only moderately effective and is limited by adverse effects (see Appendix). Spasticity is a central feature of multiple sclerosis (MS), cerebral palsy and spinal cord injury. Tremor, ataxia and incontinence also contribute to the high incidence of anxiety and depression in these conditions. Cannabis was often used to treat pain, muscle spasm, cramps and ataxia in the 19th century, and many modern sufferers have reported benefits (Grinspoon \& Bakalar, 1993).

Most respondents to a questionnaire sent to British and American MS patients reported problems with symptom control (Consroe et al, 1997). Those who smoked cannabis claimed improvements in nighttime spasticity and muscle pain (91-98\%); night leg pain, depression, tremor, anxiety, spasms on walking, paraesthesiae (80$89 \%)$; leg weakness, trunk numbness, facial pain $(71-74 \%)$; impaired balance $(57 \%)$; constipation $(33 \%)$; memory loss $(31 \%)$.

In a small single-blind comparison with placebo (Clifford, 1983), THC improved tremor and ataxia in most patients. All experienced a 'high' at the top dose $(15 \mathrm{mg})$, and two reported dysphoria. Dose-related improvements in dystonia were noted in five patients given cannabidiol 100 $600 \mathrm{mg}$ daily for 6 weeks. Hypotension, dry mouth, sedation and light-headedness occurred but were described as mild. Parkinsonian symptoms were aggravated in two subjects.

An RCT by Petro \& Ellenberger (1981) compared the effects of placebo and THC in doses of 5 or $10 \mathrm{mg}$ on muscle tone, reflexes and muscle power in nine MS patients. Both doses of THC reduced 
Table I Human randomised controlled trials (RCTs): anti-emetic effects

\begin{tabular}{|c|c|c|c|}
\hline Study & Subjects & Study design & Results \\
\hline Sallan et al (1975) & $\begin{array}{l}22 \text { patients mainly resistant to } \\
\text { conventional anti-emetics }\end{array}$ & $\begin{array}{l}\mathrm{db}, \mathrm{pc}, \mathrm{r}, \mathrm{x}, \mathrm{sd} \\
\mathrm{THC} 10 \mathrm{mg} / \mathrm{m}^{2}\end{array}$ & $\begin{array}{l}\text { THC significantly superior to placebo. Sedation and euphoria } \\
\text { occurred in the majority of patients in THC phase }\end{array}$ \\
\hline Chang et al (1979) & $\begin{array}{l}\text { I5 patients on high-dose } \\
\text { methotrexate }\end{array}$ & $\begin{array}{l}\mathrm{db}, \mathrm{pc}, \mathrm{r}, \mathrm{x}, \mathrm{md} ; \mathrm{THC} \\
\text { oral } 10 \mathrm{mg} / \mathrm{m}^{2} \\
\text { smoked approx. } 17 \mathrm{mg}\end{array}$ & $\begin{array}{l}\text { "Fourteen of I5 patients had a reduction in nausea and } \\
\text { vomiting on THC as compared to placebo" }\end{array}$ \\
\hline Einhorn et al (198I) & $\begin{array}{l}100 \text { patients on cancer } \\
\text { chemotherapy }\end{array}$ & $\begin{array}{l}\text { db, } r, x, \mathrm{md} \text {; nabilone } \\
2 \mathrm{mg} \text { q.d.s.; prochlorperazine } \\
10 \mathrm{mg} \text { q.d.s. }\end{array}$ & $\begin{array}{l}\text { Nabilone was significantly superior in reducing nausea and vo- } \\
\text { miting frequency, but produced more lethargy and } \\
\text { hypotension. Nabilone was preferred by } 75 \% \text { of patients }\end{array}$ \\
\hline Orr \& McKernan (I98I) & $\begin{array}{l}55 \text { patients on cancer } \\
\text { chemotherapy }\end{array}$ & $\begin{array}{l}\mathrm{db}, \mathrm{pc}, \mathrm{r}, \mathrm{x}, \mathrm{md} ; \mathrm{THC} \\
7 \mathrm{mg} \text { q.d.s.; prochlorperazine } \\
7 \mathrm{mg} \text { q.d.s. }\end{array}$ & $\begin{array}{l}\text { THC was significantly superior to prochlorperazine }(P<0.005) \text {. } \\
\text { Side-effects were evenly distributed, except that THC } \\
\text { produced a 'high' in } 82 \% \text { of patients }\end{array}$ \\
\hline Jones et al (1982) & $\begin{array}{l}54 \text { patients on various } \\
\text { chemotherapy } \\
\text { ( } 24 \text { evaluable) }\end{array}$ & $\begin{array}{l}\mathrm{db}, \mathrm{pc}, \mathrm{r}, \mathrm{x}, \mathrm{md} \text {; nabilone } \\
2 \mathrm{mg}\end{array}$ & $\begin{array}{l}\text { Nabilone reduced mean number of vomiting episodes } \\
(P<0.00 \mathrm{I}) \text { and nausea }(P<0.00 \mathrm{I}) \text { in comparison with placebo. } \\
\text { Side-effects common but "acceptable" }\end{array}$ \\
\hline Ungerleider et al (1982) & $\begin{array}{l}214 \text { patients on various } \\
\text { chemotherapy }\end{array}$ & $\begin{array}{l}\mathrm{db}, \mathrm{r}, \mathrm{x}, \mathrm{md} \text {; THC } 7.5- \\
\text { 12.5 mg prochlorperazine }\end{array}$ & $\begin{array}{l}\text { No significant difference in anti-nausea and vomiting between } \\
\text { the two drugs. More side-effects on THC, yet more patients } \\
\text { preferred it }\end{array}$ \\
\hline $\begin{array}{l}\text { Niiranen \& Mattson } \\
\text { (1985) }\end{array}$ & $\begin{array}{l}24 \text { patients on various } \\
\text { chemotherapy }\end{array}$ & $\begin{array}{l}\mathrm{db}, \mathrm{r}, \mathrm{x}, \mathrm{sd} \text {; nabilone } 2 \mathrm{mg} v \text {. } \\
15 \mathrm{mg} \text { prochlorperazine }\end{array}$ & $\begin{array}{l}\text { Nabilone significantly superior in reducing vomiting. More } \\
\text { side-effects yet majority of patients preferred it }\end{array}$ \\
\hline Dalzell et al (1986) & $\begin{array}{l}23 \text { children on various } \\
\text { chemotherapy }\end{array}$ & $\begin{array}{l}\mathrm{db}, \mathrm{r}, \mathrm{x}, \mathrm{md} \text {; nabilone } \mathrm{v} . \\
\text { domperidone }\end{array}$ & $\begin{array}{l}\text { Significantly fewer vomiting episodes and less nausea on } \\
\text { nabilone. More side-effects, but } 2 / 3 \text { children preferred it }\end{array}$ \\
\hline Niederle et al (1986) & 20 patients on cisplatin & $\begin{array}{l}\mathrm{db}, \mathrm{r}, \mathrm{x}, \mathrm{md} \text {; nabilone } 2 \mathrm{mg} \\
\text { b.d., alizapride } 150 \mathrm{mg} \text { t.d.s. }\end{array}$ & $\begin{array}{l}\text { Nabilone reduced emesis and relieved nausea significantly } \\
\text { better than alizapride but caused more adverse effects }\end{array}$ \\
\hline Pomeroy et al (1986) & $\begin{array}{l}38 \text { patients on various } \\
\text { chemotherapy }\end{array}$ & $\begin{array}{l}\mathrm{db}, \mathrm{r}, \mathrm{md} \text {; nabilone I mg v. } \\
\text { domperidone } 20 \mathrm{mg}\end{array}$ & $\begin{array}{l}\text { Mean number of vomiting episodes in two cycles of treatment } \\
\text { was } 4.53 \text { for nabilone and } 10.8 \mathrm{I} \text { for domperidone }(P<0.0 \mathrm{I})\end{array}$ \\
\hline Chan et al (1987) & $\begin{array}{l}30 \text { children with } \\
\text { chemotherapy-induced } \\
\text { emesis }\end{array}$ & $\begin{array}{l}\mathrm{db}, \mathrm{r}, \mathrm{x}, \mathrm{md} \text {; nabilone } \mathrm{v} \text {. } \\
\text { prochlorperazine }\end{array}$ & $\begin{array}{l}\text { Improvement of retching and emesis was } 70 \% \text { during nabilone } \\
\text { and } 30 \% \text { during prochlorperazine }(P=0.015)\end{array}$ \\
\hline Lane et al (1991) & $\begin{array}{l}62 \text { patients on various } \\
\text { chemotherapy }\end{array}$ & $\begin{array}{l}\mathrm{db}, \mathrm{r}, \mathrm{md} \text {; dronabinol } \\
10 \mathrm{mg} \text { q.d.s.; prochlorperazine } \\
10 \mathrm{mg} \text { q.d.s.; or both }\end{array}$ & $\begin{array}{l}\text { Percentage of patients with any nausea or vomiting was } 51 \% \text { for } \\
\text { dronabinol group and } 83 \% \text { for prochlorperazine. A combina- } \\
\text { tion of the two drugs was significantly better than either alone }\end{array}$ \\
\hline
\end{tabular}

o, open; sb, single-blind; db, double-blind; pc, placebo-controlled; r, randomised; x, cross-over design; sd, single-dose; md, multiple-dose; q.d.s., four times daily; b.d., twice daily; THC, tetrahydrocannabinol.

spasticity $(P<0.005)$. One patient receiving THC $10 \mathrm{mg}$ and one patient receiving placebo felt 'high' but no other side-effects were recorded. In a small RCT (Ungerleider et al, 1987) with 5-day treatment periods, THC $7.5 \mathrm{mg}$ significantly improved spasticity in comparison with placebo. Nabilone $1 \mathrm{mg}$ on alternate days was compared with placebo in a double-blind randomised crossover trial with 4-week treatment periods in a single MS patient. Nocturia, muscle spasm and general well-being showed striking improvement during each active treatment period. Mild sedation was noted on active medication.

Cannabidiol had no beneficial effects in 15 patients with Huntington's disease (Consroe et al, 1991). Posture and balance were impaired by a single dose of smoked THC in $10 \mathrm{MS}$ patients and 10 non-MS volunteers (Greenberg et al, 1994), but there was no active control to determine the effects of standard anti-spastic medication in this model.

Possible sites of action of cannabinoids in dystonia include basal ganglia, cerebellum, spinal motor neurons, somatic nerves and neuromuscular junction.

\section{Loss of appetite and weight in cancer and AIDS}

Several studies have investigated effect on appetite and weight (Table 2). The appetitestimulating effect of cannabis was confirmed in fasting and non-fasting volunteers in an RCT of oral THC with alcohol, amphetamine and placebo (Hollister, 1971). A standardised THC smoking regime over 25 days in a residential laboratory was 
associated with significant increases in calorie intake and frequency of eating occasions in comparison with placebo.

Open studies in cancer patients also showed appetite improvements and slowing of weight loss. Regelson et al's (1976) RCT explored the effect on appetite (and mood) of oral THC in 54 cancer patients over a 2 -week period. There were nine withdrawals due to side-effects (six in THC period - dizziness, disassociation, confused thinking, panic, "feelings of disturbance"; three in the placebo period - anxiety, fits, dizziness, lethargy, weakness). Patients receiving THC in the first period gained weight $(P<0.05)$, and those receiving placebo first showed reduced weight loss on transfer to THC $(P<0.05)$. Depression, tranquillity and "forthrightness" scores all improved on THC. In a quarter of the patients, somnolence, dizziness and disassociation were severe enough to negate these effects.

Many people with AIDS have claimed that smoking marijuana inhibits nausea, improves appetite, reduces anxiety, relieves aches and pains, improves sleep and inhibits oral candidiasis. A small pilot study supported the hypothesis that dronabinol might reduce weight loss or even promote weight gain (Plasse et al, 1991).
Beal et al (1995) conducted an RCT over 42 days of treatment with dronabinol $5 \mathrm{mg}$ daily in 139 AIDS patients who had lost at least $2.3 \mathrm{~kg}$. Six receiving dronabinol and three receiving placebo withdrew because of "perceived drug toxicity". Dronabinol boosted appetite in comparison to placebo $(P<0.015)$ and nausea was reduced $(P=0.05)$. Improvement in mood was a strong trend $(P=0.06)$ and there was a tendency toward weight gain $(P=0.1)$. Dronabinol produced more adverse effects than placebo $(P<0.001)$, but $75 \%$ of these were mild or moderate. Most frequent were euphoria (9), dizziness (5), thinking abnormalities (5) and sedation (4).

Further investigation is amply justified. Careful monitoring of possible effects upon the immune system is needed, although a prospective multi-centre study (Kaslow et al, 1989), which followed nearly 5000 HIV-positive men for 18 months, showed no link between use of psychoactive substances and mean $\mathrm{T}$-cell counts or progression to AIDS.

\section{Pain}

Cannabinoids are effective analgesics in animal models with non-opiate mechanisms predominating. There are many anecdotal reports (Grinspoon \& Bakalar, 1993) of benefits in bone and joint pain, migraine, cancer pain, menstrual cramps and labour.

Five small RCTs (Table 3 ) show that THC is significantly superior to placebo and produces dose-related analgesia peaking at around 5 hours, comparable to but out-lasting that of codeine. Side-effects were also dose-related, and consisted of slurred speech, sedation and mental clouding, blurred vision, dizziness and ataxia. Levonantradol was also superior to placebo and notably long-acting, but almost half the patients reported sedation. Cannabinoids may have considerable potential in neuropathic pain (Institute of Medicine, 1999).

\section{Raised intra-ocular pressure}

Glaucoma due to obstructed outflow of aqueous humour or anatomical eye defects is the most common cause of blindness in the Western world. Some RCTs investigating this area are given in Table 4.

There have been many anecdotal reports that street marijuana can relieve glaucoma symptoms and individuals have successfully argued in the USA for legal access to the drug (Grinspoon \& Bakalar, 1993). A pilot study of smoked marijuana

Table 2 Human randomised controlled trials (RCTs): appetite and weight

\begin{tabular}{|c|c|c|c|}
\hline Study & Subjects & Study design & Results \\
\hline Hollister (197I) & $\begin{array}{l}\text { i. } 12 \text { fasting volunteers } \\
\text { ii. } 12 \text { non-fasting volunteers }\end{array}$ & $\begin{array}{l}\text { i. db, pc, r, x, sd; THC } 0.5 \mathrm{mg} / \mathrm{kg} \text {; } \\
\text { I ml } / \mathrm{kg} 95 \% \text { ethanol; } 0.2 \mathrm{mg} / \mathrm{kg} \\
\text { dexamphetamine } \\
\text { ii. db, pc, r, x, sd; THC } 0.35 \mathrm{mg} / \mathrm{kg} \\
\text { ethanol as in i }\end{array}$ & $\begin{array}{l}\text { There was large variation between subjects, but "those results } \\
\text { confirm the notion that marijuana has a stimulating effect upon } \\
\text { appetite and food consumption" }\end{array}$ \\
\hline
\end{tabular}

Regelson et al (1976) 54 patients with cancer

$\mathrm{db}, \mathrm{pc}, \mathrm{r}, \mathrm{x}, \mathrm{md}$; oral THC $0.1 \mathrm{mg} / \mathrm{kg}$ t.d.s.

\author{
Il patients with \\ anorexia nervosa \\ $\mathrm{db}, \mathrm{pc}, \mathrm{r}, \mathrm{x}, \mathrm{md}$; THC 7.5-10 mg \\ daily; diazepam (active placebo) \\ 3-15 mg/day
}

Foltin et al (1986) 9 volunteers

Beal et al (1995) sb, pc, r, x, md; marijuana

(I.84\% THC)
139 patients with

AIDS-related anorexia and weight loss
"THC stimulates appetite and helps retard the chronic weight loss associated with cancer". "Limiting side-effects which restrict use in $25 \%$ patients are somnolence, dizziness, and disassociation"
"THC is not efficacious, in short-term administration, in the treatment of primary anorexia nervosa and is associated with significant psychic disturbances in some PAN patients"

"Smoked marijuana can produce significant increases in food intake with small groups of subjects in a residential laboratory setting"

$\mathrm{db}, \mathrm{pc}, \mathrm{r}, \mathrm{md}$; dronabinol $2.5 \mathrm{mg}$ b.d. In comparison with placebo, dronabinol improved appetite $(P=0.015)$, mood $(P=0.06)$ and decreased nausea $(P=0.05)$.

There was a trend toward weight stabilisation $(P=0.1)$

o, open; sb, single-blind; db, double-blind; pc, placebo-controlled; r, randomised; x, cross-over design; sd, single-dose; md, multiple-dose; t.d.s., three times daily; b.d., twice daily; PAN, primary anorexia nervosa; THC, tetrahydrocannabinol. 
and oral THC $(15 \mathrm{mg})$ in 11 glaucoma patients found an average intra-ocular pressure (IOP) reduction of $30 \%$ in seven subjects and no response in four (Hepler et al, 1976).

Randomised controlled trials in volunteers confirmed that oral, injected or smoked cannabinoids produce dose-related reductions of IOP (Hepler et al, 1976; Perez-Reyes et al, 1976). Conjunctival engorgement and tear reduction were often noted. THC, $\Delta^{8}$-THC and 11-hydroxy- THC are more effective than cannabinol, while cannabidiol was without effect. Tolerance may develop on multiple dosing.

An RCT in patients showed IOP reductions of similar magnitude following smoked THC along with "alterations in mental status" and tachycardia (Merritt et al, 1980). THC eyedrops produced doserelated IOP reduction with minimal sideeffects though parallel reductions in the untreated eye (also seen in animal models) suggested a systemic rather than local mode of action.

\section{Insomnia, anxiety and depression}

Randomised controlled trials investigating insomnia, anxiety and depression are given in Table 5.

Nabilone ( $1 \mathrm{mg}$ three times daily) produced "dramatic improvements" on the Hamilton Anxiety Scale in 20 anxious patients in comparison to placebo $(P<0.001)$, which were mirrored by other measures (Fabre \& McLendon, 1981). Seven days into the study, nabilone patients' anxiety scores were halved, and this persisted unchanged throughout treatment. Side-effects included dry mouth, dry eyes and drowsiness. The authors concluded that nabilone is a "very effective anxiolytic deserving of further study". In a cross-over comparison of nabilone (1$2.5 \mathrm{mg}$ twice daily) and placebo in 11 anxious patients (Ilaria et al, 1981), significant improvements in anxiety scores $(P<0.05)$ were again noted. The only clinically significant adverse effect was postural hypotension with related dizziness, lightheadedness or weakness. This was doserelated, experienced by most patients, and tended to tolerate out over time.

Preliminary data suggest that cannabidiol $(160 \mathrm{mg})$ may be an effective hypnotic, and that THC $(0.1 \mathrm{mg} / \mathrm{kg})$ may have antidepressant properties in cancer patients and others (Grinspoon \& Bakalar, 1993).

\section{Epilepsy}

Epilepsy afflicts $1 \%$ of the world's population. Conventional anticonvulsants provide unsatisfactory control for up to $30 \%$ of patients, and all can produce disabling or even life-threatening adverse effects.
The effect of cannabinoids on seizure activity in laboratory animals is complicated. Cannabidiol is a powerful anticonvulsant free of tolerance, but its profile varies between species. THC can produce seizures in big doses or when genetically seizure-sensitive animals are used, yet it is also robustly anticonvulsant in certain seizure models. A lack of stereospecificity suggests that the mechanism may not be related to a single receptor interaction. Serotonin, $\gamma$-aminobutyric acid, acetylcholine or prostaglandin systems may be involved.

There are many anecdotal reports of beneficial effects in humans with epilepsy (Grinspoon \& Bakalar, 1993) but research data are virtually non-existent. Two singlecase reports (Keeler \& Reifler, 1967; Consroe et al, 1975) give confounding information. A young man suffered seizures on his regular medication and began smoking several cannabis cigarettes nightly alongside this. No further seizures occurred while this combination was maintained. In contrast, a man with grand mal epilepsy stopped taking anticonvulsants and suffered no fits for 6 months. He then smoked cannabis on seven occasions over a 3-week period and suffered three fits during this time, although not coincident with actual intoxication.

Only one RCT (Cunha et al, 1980) exists. Fifteen poorly controlled patients

Table 3 Human randomised controlled trials (RCTs): pain

\begin{tabular}{|c|c|c|c|}
\hline Study & Subjects & Study design & Results \\
\hline Noyes et al (1975a) & $\begin{array}{l}10 \text { patients with cancer } \\
\text { pain }\end{array}$ & $\begin{array}{l}\mathrm{db}, \mathrm{pc}, \mathrm{r}, \mathrm{x}, \mathrm{sd} ; \mathrm{THC} 5,10,15 \\
\& 20 \mathrm{mg}\end{array}$ & $\begin{array}{l}\text { "Pain relief significantly superior to placebo was demonstrated } \\
\text { at high dose levels }(15,20 \mathrm{mg}) \text { " }\end{array}$ \\
\hline Noyes et al (1975b) & $\begin{array}{l}36 \text { patients with cancer } \\
\text { pain }\end{array}$ & $\begin{array}{l}\mathrm{db}, \mathrm{pc}, \mathrm{r}, \mathrm{x}, \mathrm{md} \text {; THC } 20 \mathrm{mg} \text {, } \\
\text { codeine } 120 \mathrm{mg}\end{array}$ & $\begin{array}{l}\text { Codeine and THC were equally effective, but higher dose of } \\
\text { THC sedated most patients and some found its psychoactive } \\
\text { effects uncomfortable }\end{array}$ \\
\hline Jain et al (198I) & $\begin{array}{l}56 \text { patients with } \\
\text { postoperative pain }\end{array}$ & $\begin{array}{l}\mathrm{db}, \mathrm{pc}, \mathrm{r}, \mathrm{sd} \text {; levonantradol } \\
\mathrm{I} .5,2,2.5 \text { or } 3 \mathrm{mg} \text { i.m. }\end{array}$ & $\begin{array}{l}\text { All doses significantly superior to placebo (at least } P<0.05 \text { ), but } \\
\text { no dose-response effect; } 57 \% \text { patients reported at least one } \\
\text { side-effect, but "general acceptability was good" }\end{array}$ \\
\hline Maurer et al (1990) & $\begin{array}{l}\text { I patient with spinal } \\
\text { cord injury }\end{array}$ & $\begin{array}{l}\mathrm{db}, \mathrm{pc}, \mathrm{r}, \mathrm{x}, \mathrm{md} \text {; THC } 5 \mathrm{mg} \text {, } \\
\text { codeine } 50 \mathrm{mg}\end{array}$ & $\begin{array}{l}\text { "Delta-9-THC and codeine both had an analgesic effect in } \\
\text { comparison with placebo. Only THC showed a significant effect } \\
\text { on spasticity" }\end{array}$ \\
\hline Holdcroft et al (1997) & $\begin{array}{l}\text { I patient with GI } \\
\text { tract pain (familial } \\
\text { Mediterranean fever) }\end{array}$ & $\begin{array}{l}\mathrm{db}, \mathrm{pc}, \mathrm{x}, \mathrm{md} ; \mathrm{THC} 50 \mathrm{mg} \\
\text { daily }\end{array}$ & $\begin{array}{l}\text { Morphine requirement significantly reduced }(P<0.0 \text { I) during } \\
\text { active treatment }\end{array}$ \\
\hline
\end{tabular}

o, open; sb, single-blind; db, double-blind; pc, placebo-controlled; r, randomised; x, cross-over design; sd, single-dose; md, multiple-dose; i.m., intramuscularly; GI, gastrointestinal; THC, tetrahydrocannabinol. 
Table 4 Human randomised controlled trials (RCTs): raised intra-ocular pressure (IOP)

\begin{tabular}{|c|c|c|c|}
\hline Study & Subjects & Study design & Results \\
\hline Hepler et al (1976) & $\begin{array}{l}\text { i. } 429 \text { normal volunteers } \\
\text { ii. } 48 \text { hospitalised subjects } \\
\text { iii. Il patients with glaucoma }\end{array}$ & $\begin{array}{l}\text { i. db, pc, r, sd; smoked THC I, } 2 \text { \& } \\
\text { 4\%; oral THC I5, } 30 \text { \& } 40 \text { mg } \\
\text { ii. sb, pc, md; smoked THC I \& } 2 \% \\
\text { iii. o; smoked THC I, } 24 \% \text { oral } \\
\text { THC I5 mg }\end{array}$ & $\begin{array}{l}\text { i. "dose-related and statistically significant effect in } \\
\text { reducing acutely the intraocular pressure"; } \\
\text { "pressure drop was in the range of } 30 \% \text { for } 2 \% \text { THC' } \\
\text { ii. "consistent drop in IOP around } 30 \% \text { for } 2 \% \text { THC" } \\
\text { and "no indications of cumulative effects upon IOP" } \\
\text { iii. } 7 \text { patients showed a similar response to the above, } \\
4 \text { patients had no demonstrable drug effect }\end{array}$ \\
\hline Perez-Reyes et al (1976) & I2 normal volunteers & $\begin{array}{l}\text { sb, } p c, r, x, s d ; \text { i.v. infusion of } \\
\text { various cannabinoids }\end{array}$ & $\begin{array}{l}\text { " } \Delta^{8} \text {-THC, } \Delta^{9}-\text { THC, and II-hydroxy-THC produced } \\
\text { significant reductions in IOP, whereas cannabinol, } \\
8-\beta-O H-T H C \text { and cannabidiol were less effective" }\end{array}$ \\
\hline Merritt et al (1980) & I8 patients with glaucoma & $\begin{array}{l}\mathrm{db}, \mathrm{pc}, \mathrm{sd} ; \text { smoked } \\
\text { marijuana }-\mathrm{THC}=2 \%\end{array}$ & $\begin{array}{l}\text { Significant reductions in IOP, but hypotension, tachy- } \\
\text { cardia, palpitations and psychotropic effects "mitigate } \\
\text { against routine use in the general glaucoma population" }\end{array}$ \\
\hline Merritt et al (198I) & $\begin{array}{l}8 \text { patients with "hypertensive } \\
\text { glaucoma" }\end{array}$ & $\begin{array}{l}\text { db, pc, sd; THC eye drops; } \\
0.01 \%, 0.05 \%, 1 \%\end{array}$ & $\begin{array}{l}\text { Dose-related reductions in IOP; I\% drops produced } \\
\text { mild hypotension, no psychic effects at any dose. Effect } \\
\text { in both eyes suggests systemic mechanism of action }\end{array}$ \\
\hline Jones et al (198I) & I3 normal volunteers & $\mathrm{db}, \mathrm{pc}, \mathrm{x}, \mathrm{md} ; \mathrm{10-30} \mathrm{mg}$ THC 4-hourly & $\begin{array}{l}\text { Significant reductions in IOP tend to tolerate out after } \\
\text { I0 days regular dosing. Abrupt withdrawal of THC } \\
\text { produces rebound increase in pressure above baseline }\end{array}$ \\
\hline
\end{tabular}

o, open; sb, single-blind; db, double-blind; pc, placebo-controlled; r, randomised; x, cross-over design; sd, single-dose; md, multiple-dose; i.v., intravenous;

THC, tetrahydrocannabinol.

Table 5 Human randomised controled trials (RCTs): insomnia, anxiety, depression

\begin{tabular}{|c|c|c|c|}
\hline Study & Subjects & Study design & Results \\
\hline Regelson et al (1976) & 54 patients with cancer & $\begin{array}{l}\mathrm{db}, \mathrm{pc}, \mathrm{r}, \mathrm{x}, \mathrm{md} \text {; oral THC } \\
0.1 \mathrm{mg} / \mathrm{kg} \text { t.d.s. }\end{array}$ & $\begin{array}{l}\text { "THC in cancer patients at acceptable dosage } \\
(0.1 \mathrm{mg} / \mathrm{kg} \text { t.i.d. orally) had the effect of a tranquilli- } \\
\text { ser and mild mood elevator, clearly without unto- } \\
\text { ward effect on personality or emotional stability" }\end{array}$ \\
\hline
\end{tabular}

$\begin{array}{ll}\text { Fabre \& McLendon (198I) } 20 \text { anxious patients } & \mathrm{db}, \mathrm{pc}, \mathrm{r}, \mathrm{md} \text {; nabilone } \\ 2-8 \mathrm{mg} / \mathrm{day}\end{array}$

Ilaria et al (198I)
II patients with anxiety $\mathrm{db}, \mathrm{pc}, \mathrm{r}, \mathrm{x}, \mathrm{md}$; nabilone

I-2.5 mg b.d.
A "dramatic improvement in anxiety in the nabilone group when compared with placebo $(P<0.00 \mathrm{I})$ " was reported. More dropouts from the placebo group $(P<0.03)$. Dry mouth and eyes and drowsiness were the most common adverse effects

Nabilone was superior to placebo $(P<0.05)$ in relieving anxiety scores on Hamilton Anxiety Scale and Global Improvement Scale

o, open; sb, single-blind; db, double-blind; pc, placebo-controlled; r, randomised; x, cross-over design; sd, single-dose; md, multiple-dose; t.d.s., three times daily; b.d., twice daily; THC, tetrahydrocannabinol. 
with secondary generalised epilepsy continued with their regular therapy but were also given either cannabidiol or placebo daily for up to 4.5 months while undergoing regular clinical and electroencephalogram evaluation. Half the patients on cannabidiol remained "almost free" of fits throughout the experiment, and all but one of the others showed "partial improvement". All but one of the placebo patients remained entirely unchanged. Somnolence occurred in four patients receiving cannabidiol.

\section{Asthma}

Small-scale controlled studies in volunteers with asthma show that oral, smoked and aerosolised THC has comparable bronchodilatory activity to salbutamol, although onset is quicker with the latter. Dose-related tachycardia occurred in some individuals, and subjective intoxication with higher doses. A THC aerosol was free of systemic unwanted effects, but was irritant to the lungs (Tashkin et al, 1977). Nabilone does not produce bronchodilation. Since THCinduced bronchodilation is not mediated through the sympathetic nervous system, synergistic combinations with $\beta_{2}$-adrenoceptor stimulants might be possible.

\section{Other possible therapeutic applications}

Basic research indicates that THC and analogues inhibit opioid withdrawal (Chesher \& Jackson, 1985). Anecdotal reports from patients also point to beneficial effects beyond those which could be accounted for by sedative or hypnotic activity. Cannabinoids inhibit primary tumour growth and increase survival in animal tumour models (Harris et al, 1976) by an unknown mechanism. They also show antipyretic and anti-inflammatory activity (Formukong et al, 1989). Mechoulam (1986) has drawn attention to the lack of modern research directed at possible antihelmintic, antimigraine and oxytocic applications.

\section{DISCUSSION}

\section{Therapeutic profile on existing evidence}

Tetrahydrocannabinol and nabilone are effective anti-emetics but there are no comparisons with $5-\mathrm{HT}_{3}$ antagonists, so a role in modern anti-emetic regimes remains to be determined. Currently, only nabilone is licensed in the UK and available for prescription and research. THC (as dronabinol) has recently been rescheduled to permit prescription but remains unlicensed and must be specially imported on a named-patient basis. Delta-8-THC looks worthy of further investigation, particularly in children, and is much simpler to synthesise than THC.

Many individuals with MS have claimed a benefit from cannabis and small controlled trials support this, although effect upon posture and balance requires clarification. THC is an effective analgesic at the expense of sedation with larger doses and may have special merit in neuropathic pain. No conclusions are possible as yet about anticonvulsant potential. Some cannabinoids reduce IOP, though side-effects of products currently available limit application and effects of tolerance are uncertain. The mechanism for bronchodilation probably differs from that of $\beta_{2}$-stimulants, so synergistic combinations may be possible.

Cannabis and THC are effective appetite stimulants. Alongside anti-emetic, analgesic, anxiolytic, hypnotic and antipyretic properties this suggests a unique role in alleviating symptoms in selected patients with cancer or AIDS. This is a compelling area for future research, although possible effects upon immune function require careful monitoring.

Optimal doses and routes of delivery have not been established. Absorption by the oral route is unreliable. Smoking the drug is generally not a viable option since advantages such as rapid onset, accurate titration of effects and reliability in patients who are vomiting have to be set against the likelihood of lung irritation or damage, and it would in any case be unacceptable to most patients. However, pending availability of more satisfactory preparations, I believe that the existing profile of efficacy and toxicity justifies the provision of a legal supply of standardised herbal material ('compassionate reefers') to patients with terminal conditions who currently obtain relief with street cannabis. Sublingual sprays or tablets, nebulisers and aerosols look promising for the future, and THC is effective by the rectal route. Many potentially active cannabinoids have yet to be investigated and the recent identification of a peripheral receptor may lead to new drugs devoid of central nervous system effects.
Cannabis arouses passion in those who support or condemn it, and few people approach the clinical literature with dispassionate objectivity. Poorly controlled research produces ambiguous results which are then interpreted according to the prejudices of the reader. Anecdotes seem to be more readily accepted when they point to adverse rather than positive effects (Hall et al, 1994). Yet the known adverse effects of oral cannabinoids are rarely intolerable or life-threatening, in contrast to those associated with some standard therapies. A British Medical Association survey indicated that many UK doctors believe that cannabis should once again be available on prescription (Meek, 1994).

\section{The way forward}

A Select Committee of the House of Lords recently examined the scientific information concerning medical cannabis and took verbal and written evidence from a wide range of witnesses. Their conclusion (House of Lords, 1998) published in November 1998, was that, although cannabis should remain a controlled drug, the law should be changed to allow doctors to prescribe "an appropriate preparation of cannabis if they saw fit". The government rejected this recommendation on the day of publication.

Under the auspices of the Royal Pharmaceutical Society, large-scale multicentre trials are under way to explore further the efficacy of cannabinoids in relieving spasticity and postoperative pain. A pharmaceutical company has obtained a licence to cultivate medicinal cannabis on a large scale in the UK. By selecting a specific genotype then carefully controlling all other relevant variables such as soil conditions, temperature and humidity, it is possible to obtain levels of purity in plant extracts equal or superior to those of 'pure' synthetic cannabinoids. Most of the 60 or so naturally occurring cannabinoids are present in tiny amounts, and synthetic cannabinoids such as nabilone themselves contain up to $5 \%$ impurities, some of which are of unknown identity. Whether obtained by synthetic means or by plant extraction, it is essential that cannabinoids for prescription and research in the future should demonstrate excellent purity, stability and bioavailability.

The medicinal properties of cannabis are still mainly delineated by the anecdotal reports of those who believe their symptoms 
are relieved by its use, and these accounts are often dismissed as wishful thinking or even mischievous. Since the conventional treatments for many of these disorders are both toxic and relatively ineffectual, a more constructive response would be to expose such claims to careful scientific examination and, in the meantime, search for a way to avoid criminalising those who seek only to assuage their own suffering.

\section{ACKNOWLEDGEMENT}

This review was originally commissioned and funded by the Department of Health. The author thanks Dr Anthony Thorley for his support and encouragement. The views expressed in the paper are those of the author and not necessarily of the Department of Health.

\section{APPENDIX}

\section{Existing anti-emetics}

Phenothiazzines and butyrophenones can cause sedation, movement disorders which may be irreversible, neuroleptic malignant syndrome, dry mouth, blurred vision, urinary retention, hypotension, allergic reactions, jaundice, hypothermia, hormonal disturbances, irreversible eye damage and, rarely, life-threatening anaemias. Domperidone has a more benign profile but is not recommended for long-term use. Metoclopramide produces movement disorders ( $1 \%$ of patients), dizziness and drowsiness. Selective $5-\mathrm{HT}_{3}$ antagonists (ondansetron, granisetron) are newer and more expensive. Side-effects include constipation, headache, flushing, liver enzyme changes, allergic reactions, visual disturbances, chest pain and dysrhythmias.

\section{Existing neurological treatments}

Baclofen alleviates spasticity, but may accentuate muscle weakness. It produces dose-related nausea and vomiting, drowsiness, vertigo, confusion, fatigue and hypotonia. Less commonly, fits, psychiatric disorder and hypotension occur. Sudden withdrawa can cause hallucinations. Diazepam is useful but can worsen weakness or incoordination and cause drowsiness, ataxia, depression, disinhibition and dependence. Dantrolene may cause weakness, hypotonia, drowsiness, dizziness, vertigo and anxiety. Rarely, it damages the liver, and is not recommended in those with co-existing heart or lung disease.

\section{Existing glaucoma treatments}

Eye-drops. Miotics can produce blurring of vision, headache, and parasympathetic effects including sweating, bradycardia, colic and bronchospasm. Adrenaline often causes local discomfort. Dipivefrine and guanethidine may cause conjunctival fibrosis on chronic use. Beta-blockers may cause bradycardia, heart block or bronchoconstriction.

Systemic drugs (acetazolamide, dichlorphenamide) can cause hypokalaemia, appetite suppression, paraesthesiae, drowsiness, depression, rashes and, rarely, bone marrow suppression.

\section{REFERENCES}

Abrahamov, A. Abrahamov, A. \& Mechoulam, R. (1995) An efficient new cannabinoid anti-emetic in pediatric oncology. Life Sciences, 56, 2097-2102.

Beal, J. E., Olson, R., Laubenstein, L., et al (1995) Dronabinol as a treatment for anorexia associated with weight loss in patients with AIDS. Journal of Pain \& Symptom Management, 10, 89-97.

Carlini, E. A. \& Cunha, J. M. (1981) Hypnotic and antiepileptic effects of cannabidiol. Journal of Clinical Pharmacology, 2I (suppl. 8-9), 4I7S-427S

Chan, H. S., Correia, J. A. \& MacLeod, S. M. (1987) Nabilone versus prochlorperazine for control of cancer chemotherapy-induced emesis in children: a doubleblind, crossover trial. Pediatrics, 79, 946-952.

Chang, A. E., Shiling, D. J., Stillman, R. C., et al (1979) Delta-9-tetrahydrocannabinol as an antiemetic in cancer patients receiving high-dose methotrexate. A prospective, randomized evaluation. Annals of Internal Medicine, 9I, 819-824.

Chesher, G. B. \& Jackson, D. M. (1985) The quasi morphine withdrawal syndrome: effect of cannabinol, cannabidiol and THC. Pharmacology, Biochemistry and Behaviour, 23, 13-15.

Clifford, D. B. (1983) Tetrahydrocannabinol for tremor in multiple sclerosis. Annals of Neurology, 13, 669-67I.

Consroe, P. F., Wood, G. C. \& Buchsbaum, H. (1975) Anticonvulsant nature of marihuana smoking. Journal of the American Medical Association, 234, 306-307.

_ , Laguna, J., Allender, J., et al (199I) Controlled clinical trial of cannabidiol in Huntington's disease. Pharmacology, Biochemistry and Behavior, 40, 70I-708.

_, Musty, R., Rein, J., et al (1997) The perceived effects of smoked cannabis on patients with multiple sclerosis. European Neurology, 38, 44-48.

Cunha, J. M., Carlini, E. A., Pereira, A. E., et al (1980) Chronic administration of cannabidiol to healthy volunteers and epileptic patients. Pharmacology, 2I, 175-185

Dalzell, A. H., Bartlett, H. \& Lilleyman, J. S. (1986) Nabilone: an alternative antiemetic for cancer chemotherapy. Annals of Diseases of Childhood, $6 \mathbf{1}$ 502-505.

Doblin, R. E. \& Kleiman, M. A. R. (1991) Marijuana as anti-emetic medicine: a survey of oncologists' experiences and attitudes. Journal of Clinical Oncology, $\mathbf{9}$, 1314-1319.

Einhorn, L. H., Nagy, C., Furnas, B., et al (1981) Nabilone: an effective antiemetic in patients receiving cancer chemotherapy. Journal of Clinical Pharmacology, $2 \mathbf{I}$ (suppl. 8-9), 64S-69S.

Fabre, L. F. \& McLendon, D. (1981) The efficacy and safety of nabilone (a synthetic cannabinoid) in the treatment of anxiety. Journal of Clinical Pharmacology, $2 \mathbf{I}$ (suppl. 8-9), 377S-382S.

Foltin, R.W., Brady, J.V. \& Fischman, M.W. (1986) Behavioral analysis of marijuana effects on food intake in humans. Pharmacology, Biochemistry and Behavior, 25, 577-582.

Formukong, E. A., Evans, A. T. \& Evans, F. J. (1989) The medicinal use of cannabis and its constituents. Phytotherapy Research, 3, 219-231.

Greenberg, H. S., Werness, S. A. S., Pugh, J. E., et al (1994) Short term effects of smoking marijuana on balance in patients with multiple sclerosis and normal volunteers. Clinical Pharmacology and Therapeutics, 55, 324-328.

Grinspoon, L. \& Bakalar, J. B. (1993) Marihuana, The Forbidden Medicine. New Haven: Yale University Press.

Gross, H., Ebert, M. H., Faden, V. B., et al (1983) A double-blind trial of delta 9-tetrahydrocannabinol in primary anorexia nervosa. Journal of Clinical Psychopharmacology, 3, 165-17|.

Hall, W., Solowij, N. \& Lemon, J. (eds) (1994) The Health and Psychological Consequences of Cannabis Use, National Drug Strategy Monograph Series No. 25. Canberra: Australian Government Publishing Service.

Harris, L. S., Munson, A. E. \& Carchman, R. A (1976) Antitumor properties of cannabinoids. In The Pharmacology of Marihuana, Vol. 2 (eds M. C. Braude \& S. Szara), pp. 749-76I. New York: Raven Press.

Hepler, R. S., Frank, I. M. \& Petrus, R. (1976) The ocular effects of marihuana smoking. In The Pharmacology of Marihuana (eds M. C. Braude \& S. Szara). New York: Raven Press.

Holdcroft, A., Smith, M., Jacklin, A., et al (1997) Pain relief with oral cannabinoids in familial Mediterranean fever. Anaesthesia, 52, 483-488.

Hollister, L. E. (197I) Hunger and appetite after single doses of marihuana, alcohol, and dextroamphetamine. Clinical Pharmacology and Therapeutics, 12, 44-49.

House of Lords Select Committee on Science and Technology (1988) Cannabis: The Scientific and Medical Evidence (HL Paper 15I). London: HMSO

Ilaria, R. L., Thornby, J. I. \& Fann, W. E. (198I) Nabilone, a cannabinol derivative, in the treatment of anxiety neuroses. Current Therapeutic Research, 29, 943-949.

Institute of Medicine (1999) Cannabinoids and animal physiology. In Marijuana and Medicine: Assessing the Science Base (eds J. E. Joy, S. J.Watson \& J. A. Benson), pp. 2.I-2.47. Washington, DC: National Academy Press.

Jain, A. K, Ryan, J. R., McMahon, F. G., et al (198I) Evaluation of intramuscular levonantradol and placebo in acute postoperative pain. Journal of Clinical Pharmacology, 21 (suppl. 8-9), 320S-326S.

Jones, R. T., Benowitz, N. L. \& Herning, R. I. (198I) Clinical relevance of cannabis tolerance and dependence. Journal of Clinical Pharmacology, $2 \mathbf{l}$ (suppl. $8-9), 1435-152 S$

Jones, S. E., Durant, J. R., Greco, F. A., et al (1982) A multi-institutional Phase III study of nabilone vs. placebo in chemotherapy-induced nausea and vomiting. Cancer Treatment Review, 9 (suppl. B), 45-48.

Kaslow, R. A., Blackwelder, W. C., Ostrow, D. G., et a (1989) No evidence for a role of alcohol or other psychoactive drugs in accelerating immunodeficiency in HIV-I-positive individuals. Journal of the American Medical Association, 261, 3424-3429.

Keeler, M. H. \& Reifler, C. B. (1967) Grand mal convulsions subsequent to marihuana use. Diseases of the Nervous System, 18, 474-475.

Lane, M., Vogel, C. L. \& Ferguson, J. (1991) Dronabinol and prochlorperazine in combination are better than either agent alone for treatment of chemotherapy-induced nausea and vomiting. Proceedings of the American Society of Clinical Oncologists, 8, 326.

Levitt, M. (1986) Cannabinoids as antiemetics in cancer chemotherapy. In Cannabinoids as Therapeutic Agents (ed. R. Mechoulam). Boca Raton, FA: CRC Press.

Maurer, M., Henn, V., Dittrich, A., et al (1990) Delta9-tetrahydrocannabinol shows antispastic and analgesic 
effects in a single case double-blind trial. European Archives of Psychiatry and Clinical Neuroscience, 240, I-4.

Mechoulam, R. (1986) The pharmacohistory of Cannabis sativa. In Cannabinoids as Therapeutic Agents (ed. R. Mechoulam), pp. I-19. Boca Raton, FL: CRC Press.

Meek, C. (1994) Doctors want cannabis prescriptions allowed. BMA News Review, 15 February, p. 15.

Merritt, J. C., Crawford, W. J., Alexander, P. C., et a (1980) Effect of marihuana on intraocular and blood pressure in glaucoma. Ophthalmology, 87, 222-228.

_ , Olsen, J. L., Armstrong, J. R., et al (198I) Topical delta 9-tetrahydrocannabinol in hypertensive glaucomas. Journal of Pharmacy and Pharmacology, 33, 40-41.

Niederle, N., Shütte, J. \& Schmidt, C. G. (1986) Crossover comparison of the antiemetic efficacy of nabilone and alizapride in patients with nonseminomatous testicular cancer receiving cisplatin therapy. Klinische Wochenschrift, 64, 362-365.

Niiranen, A. \& Mattson, K. (1985) A cross-over comparison of nabilone and prochlorperazine for emesis induced by cancer chemotherapy. American Journal of Clinical Oncology, 8, 336-340.

Noyes, R. Jr, Brunk, S. F., Baram, D. A., et al (1975a) Analgesic effect of delta-9-tetrahydrocannabinol. Journal of Clinical Pharmacology, 15, 139-143.

—, _ , Avery, D. A. H., et al (1975b) The analgesic properties of delta-9-tetrahydrocannabinol and codeine. Clinical Pharmacology and Therapeutics, 18, 84-89.

Orr, L. E. \& McKernan, J. G. (198I) Antiemetic effect of delta 9-tetrahydrocannabinol in chemotherapyassociated nausea and emesis as compared to placebo and compazine. Journal of Clinical Pharmacology, $\mathbf{2} \mathbf{I}$ (suppl. 8-9), 76S-80S.

Penta, J. S., Poster, D. S., Bruno, S., et al (198I) Clinical trials with anti-emetic agents in cancer patients receiving chemotherapy. Journal of Clinical Pharmacology 2I (suppl. 8-9), IIS-22S.

Perez-Reyes, M., Wagner, D., Wall, M. E., et al (1976) Intravenous administration of cannabinoids and intraocular pressure. In The Pharmacology of Marihuana (eds M. C. Braude \& S. Szara), pp. 829-832. New York: Raven Press.

Pertwee, R. G. (1995) Pharmacological, physiological and clinical implications of the discovery of cannabinoid receptors: an overview. In Cannabinoid Receptors (ed. R. Pertwee), pp. I-34. Harcourt Brace.

Petro, D. J. \& Ellenberger, C. (198I) Treatment of human spasticity with delta-9-tetrahydrocannabinol. Journal of Clinical Pharmacology, 2I (suppl. 8-9), 4I3S $416 \mathrm{~S}$.

\section{CLINICAL IMPLICATIONS}

- Cannabis and its derivatives show promise of beneficial effects in a number of medical conditions for which standard treatment is less than satisfactory, and further controlled research is fully justified.

Cannabis is very safe in overdose, but often produces unwanted effects which are better tolerated by patients with some conditions (e.g. multiple sclerosis, chronic pain, AIDS, cancer) than others (e.g. glaucoma).

- Optimal formulations, doses and routes of delivery have not yet been established.

\section{LIMITATIONS}

Because of imposed time constraints, the review is not fully comprehensive, although all accessed sources were incorporated.

- Much of the evidence is anecdotal, and many of the research studies cited have serious methodological shortcomings.

- Few researchers (or reviewers) approach the subject of cannabinoid therapeutics in a spirit of dispassionate objectivity.

PHILIP ROBSON, FRCPsych, Consultant Psychiatrist and Senior Clinical Lecturer, Warneford Hospital, Oxford OX3 7JX

(First received 22 July 1999, final revision 14 March 2000, accepted 15 March 2000)

Plasse, T. F., Gorter, R.W., Krasnow, S. H., et al (1991)

Recent clinical experience with dronabinol. Pharmacology, Biochemistry \& Behaviour, 40, 695-700

\section{Pomeroy, M., Fennelly, J. J. \& Towers, M. (1986)} Prospective randomized double-blind trial of nabilone versus domperidone in the treatment of cytotoxicinduced emesis. Cancer Chemotherapy and Pharmacology 17. $285-288$.

Regelson, W., Butler, J. R., Schulz, J., et al (1976) Delta-9-THC as an effective antidepressant and appetite-stimulating agent in advanced cancer patients. In The Pharmacology of Marihuana (eds M.C. Braude \& S. Szara), pp. 763-775. New York: Raven Press.

Reynolds, J. R. (1890) Therapeutic uses and toxic effects of cannabis indica. Lancet, i, 637-638.
Sallan, S. E., Zinberg, N. E. \& Frei, E. 3rd (1975) Antiemetic effect of delta-9-tetrahydrocannabinol in patients receiving cancer chemotherapy. New England Journal of Medicine, 293, 795-797.

Tashkin, D. P., Reiss, S., Shapiro, B. J., et al (1977) Bronchial effects of aerosolized delta-9-THC in healthy and asthmatic subjects. American Review of Respiratory Disease, II5, 57-65.

Ungerleider, J.T., Andrysiak, T., Fairbanks, L., et al (1982) Cannabis and cancer chemotherapy: a comparison of oral delta-9-THC and prochlorperazine. Cancer, 50, 636-645

, et al (1987) Delta-9- $\mathrm{THC}$ in the treatment of spasticity associated with multiple sclerosis. Advances in Alcoholism and Substance Abuse, 7, 39-50. 